\title{
POTRET PAUD DI DESA COMPANG NDEJING
}

\author{
Felisitas Ndeot \\ UNIKA SANTU PAULUS RUTENG \\ E-mail: icananoarta@gmail.com \\ Ndeot, Felistas. (2020). Potret PAUD di Desa Compang Ndejing. Jurnal Pelita PAUD, 4(2), 178-186. \\ doi: https://doi.org/10.33222/pelitapaud.v4i1.997
}

Diterima:14-02-2020

Disetujui: 23-04-2020

Dipublikasikan: 28-06-2020

Abstrak: Penelitian ini bertujuan untuk menyoroti keadaan satuan PAUD di Dusun Sok. Subjek penelitian ini adalah siswa, guru, dan orangtua di PAUD Santa Angela. Jenis penelitian yang dipakai adalah penelitian kualitatif dengan pendekatan deskriptif. Pengumpulan data dilakukan dengan cara observasi, wawancara, dan dokumentasi. Teknik analisis data yang digunakan adalah model Miles dan Huberman. Temuan hasil penelitian menunjukkan potret pendidik, hanya terdapat 1 orang guru tamatan SMA, serta masih kurang memiliki kompetensi profesional dan pedagogik, potret Sarana dan Prasarana, PAUD Santa Angela hanya memiliki sebuah ruangan yang digunakan sebagai ruang belajar berlantai tanah untuk memberikan layanan berupa rangsangan pendidikan kepada anak-anak yang berusia 2 hingga 6 tahun, kursi plastik yang berukuran sesuai untuk anak-anak, sebuah papan tulis kecil, gambar huruf dan angka, sebuah ayunan yang terbuat dari kayu, serta satu set lego. Toilet yang digunakan merupakan toilet rumah yang dipakai bersama dengan pemilik lahan tempat satuan PAUD berdiri.

Kata Kunci: Potret PAUD, Desa Compang Ndejing

Abstract: This study aims to highlight the state of the PAUD unit in Sok.The subjects of this research are students, teachers, and parents in PAUD Santa Angela. This type of research used is qualitative research with a descriptive approach. Data collection is done by means of observation, interviews, and documentation. The data analysis technique used is the Miles and Huberman model. The findings of the study show teacher's portrait, there are only one highschool graduate teacher, and still lack professional and pedagogical competence, portrait of facilities and Infrastructure, PAUD Santa Angela only has a room that is used as a ground floor study room to provide services in the form of educational stimuli to children aged 2 to 6 years, plastic chairs of suitable size for children, a small blackboard, a picture of letters and numbers, a swing made of wood, and a set of legos. The toilet used is the house toilet that is shared with the owner the land where the PAUD unit stands.

Keywords: Early Childhood Education portraits, Desa Compang Ndejing

http://jurnal.upmk.ac.id/index.php/pelitapaud 


\section{PENDAHULUAN}

Kehadiran satuan PAUD di desa merupakan dambaan setiap orangtua. Kesadaran masyarakat akan pentingnya rangsangan untuk mengoptimalkan berbagai aspek perkembangan pada anak sejak usia dini pada saat ini semakin meningkat. Hal tersebut dapat dilihat dari sikap antusias yang ditunjukkan oleh para orangtua untuk mendaftarkan anak di setiap satuan PAUD. APK PAUD di Indonesia sebagian besar terlihat semakin meningkat setiap tahun, pada tahun 2018 APK PAUD sudah mendekati 60\% dan tahun 2019 pemerintah menargetkan APK PAUD sebesar 77,2\% (http://spasial.data.kemdikbud.go.id). Menurut data referensi PAUD Kemdikbud (2017), Kabupaten Manggarai Timur memiliki 150 satuan PAUD dengan rincian 8 TK/RA Negeri, 13 TK/RA swasta, dan $129 \quad \mathrm{~KB}$ swasta (http://referensi.data.kemdikbud.go.id). Tentu saja jumlah ini terus meningkat hingga saat ini. Semakin tinggi minat anak untuk masuk PAUD maka semakin besar tugas pemerintah untuk mendirikan satuan PAUD yang berkualitas di setiap desa. Kompetensi pendidik dan sarana prasarana satuan PAUD merupakan bagian penting dalam penyelenggaraan PAUD yang perlu mendapatkan perhatian serius agar tercipta satuan PAUD yang berkualitas.

Guru PAUD memiliki fungsi yang sangat penting dalam kegiatan belajar dan penciptaan perilaku anak karena memiliki ikatan secara langsung dengan anak sebagai siswa. Guru PAUD menjadi model yang setiap saat dapat ditiru oleh anak melalui hubungan antara guru dan murid yang tercipta dengan erat (Puspita, 2010). Guru adalah bagian dari Sumber Daya Manusia (SDM) paling substansial dalam pelaksanaan kegiatan Pendidikan Anak Usia Dini sehingga guru PAUD wajib mempunyai kemampuan khusus yang mendukung pelaksanaan tugas-tugas pokok dalam kegiatan di satuan PAUD (Muzaqi, 2008). Guru PAUD wajib menguasai serta mampu mengimplementasikan pengetahuan dan keterampilan yang berkaitan dengan kePAUDan sehingga perkembangan anak yang mendapat layanan pendidikan pada satuan PAUD berkembang dengan sangat baik. Penyelenggaraan kegiatan di satuan PAUD akan lancar jika ditunjang dengan ketersediaan sarana dan prasarana yang memadai. Salah satu manfaat disediakan sarana dan prasarana di satuan PAUD adalah agar kegiatan belajar di satuan PAUD menjadi lebih optimal (Direktorat Pembinaan PAUD Kemdikbud, 2014). Ketersediaan sarana dan prasarana yang memadai dapat mendorong keberlangsungan kegiatan di satuan PAUD yang menyenangkan dan membuat anak merasa aman dan nyaman.

Pada saat peneliti mengumpulkan data awal, peneliti temukan fakta bahwa satuan PAUD Santa Angela hanya memiliki sebuah ruangan. Padahal, siswa yang bersekolah di tempat ini cukup banyak yaitu berjumlah 34 orang, yang terdiri dari usia 4-6 tahun (laki-laki berjumlah 17 orang dan perempuan 14 orang) dan ditemukan terdapat anak-anak yang berusia 2 tahun (1 orang), serta berusia 3 tahun (2 orang). Selain itu, layanan yang diberikan pada saat anak melakukan aktivitas bermain tidak berdasarkan usia anak. semua anak dari usia 2 hingga 6 tahun mendapat layanan dalam satu ruangan yang sama tanpa adanya pengelompokkan berdasarkan usia. Berdasarkan hasil wawancara dengan orangtua siswa, para orangtua tidak keberatan dengan keadaan ruangan yang hanya ada satu, yang paling penting adalah anak-anak mereka memiliki wadah untuk mendapatkan rangsangan atau stimulasi perkembangan sejak usia dini. Para orangtua menuturkan bahwa anak-anak yang pernah mendapatkan stimulasi di satuan PAUD Santa Angela selalu memiliki kemampuan yang lebih dibandingkan aak-anak yang tidak mendapatkan layanan di satuan PAUD pada saat sudah memasuki jenjang sekolah dasar.

Pendidik PAUD idealnya mempunyai kompetensi pedagogik, kepribadian, sosial, dan profesional (Kemendikbud, 2014). Penelitian sebelumnya menunjukkan bahwa guru PAUD memiliki kompetensi pedagogik yang baik jika mampu mengatasi masalah siswa berkaitan dengan aspekaspek perkembangan, mampu menemukan minat dan apa yang dibutuhkan anak, menemukan karakteristik masing-masing anak, menemukan cara belajar dari setiap anak, mampu memanfaatkan lingkungan sebagai media pembelajaran bagi anak, serta memahami strategi dalam meningkatkan perkembangan anak (Mustika, 2015). Penelitian lainnya menunjukkan bahwa terdapat hubungan positif yang sangat kuat dan signifikan antara motivasi kerja guru PAUD dengan kompetensi pedagogik, jika guru PAUD memiliki motivasi kerja yang tinggi maka guru PAUD juga akan memiliki kompetensi pedagogik yang tinggi (Fadilah et al., 2002). Hasil penelitianpenelitian tersebut menunjukkan bahwa kemampuan guru PAUD dalam mengajar memberikan dampak pada kualitas pembelajaran di PAUD. Adapun hasil penelitian lainnya menunjukkan bahwa ketersediaan sarana prasarana dan kompetensi guru PAUD yang memadai merupakan salah satu cara untuk meningkatkankan efektifitas layanan pendidikan di setiap satuan 
PAUD (Kurniawan, 2017). Pada dasarnya, penelitian ini akan menguraikan secara mendalam tentang keseluruhan kompetensi yang dimiliki oleh pendidik serta ketersediaan sarana dan prasarana di PAUD Santa Angela.

Penelitian ini bertujuan untuk menunjukan secara rinci mengenai keadaan pendidik dan sarana prasarana di satuan PAUD Santa Angela yang terdapat di Dusun Sok, Desa Compang Ndejing, Kecamatan Borong, Kabupaten Manggarai Timur. Diharapkan melalui hasil penelitian ini, pemerintah Kabupaten Manggarai Timur ke depannya lebih memperhatikan keadaan satuan PAUD di setiap desa yang ada dalam wilayah kabupaten Manggarai Timur secara menyeluruh demi peningkatan kualitas PAUD dalam mengahsilkan generasi penerus yang memiliki kesiapan dalam menghadapi masa-masa di usia selanjutnya.

\section{METODE PENELITIAN}

Jenis penelitian yang digunakan dalam penelitian ini adalah penelitian deskriptif yang bertujuan untuk menggambarkan atau memaparkan informasi yang terperinci mengenai potret pendidik dan sarana prasarana di satuan PAUD Santa Angela.

Penelitian ini dilaksanakan di satuan PAUD Santa Angela, Dusun Sok, Desa Compang Ndejing, Kecamatan Borong, Kabupaten Manggarai Timur, Provinsi NTT. Penelitian ini dilaksanakan sepanjang bulan November tahun 2019.

Subjek penelitian ini adalah siswa yang berjumlah 15 orang, guru 1 orang, dan orangtua siswa satuan PAUD Santa Angela sebanyak 15 orang. Peneliti memilih 15 anak dan orangtua berdasarkan keikutsertaan anak-anak dan orangtua pada saat penelitian ini berlangsung (sebagian siswa jarang datang setiap hari, hanya datang pada hari-hari tertentu). Adapun objek dalam penelitian ini adalah potret pendidik dan sarana prasarana pendidikan di satuan PAUD Santa Angela Desa Compang Ndejing.

\section{Prosedur}

Penelitian ini dilaksanakan dalam beberapa tahapan yang diadopsi dari tahapan penelitian kualitatif menurut Moleong (Shidiq \& Choiri, 2019) yaitu menyusun rencana penelitian, memilih lokasi penelitian, pelaksanaan penelitian, menganalisis data hasil penelitian. Pertama, tahap menyusun rencana penelitian. Pada tahap ini, peneliti melakukan pengamatan awal, menentukan metode yang akan digunakan, menyiapkan instrumen penelitian, serta alat transportasi menuju lokasi penelitian. Kedua, memilih lokasi penelitian. Pada tahap ini, peneliti menentukan subjek serta lokasi penelitian berdasarkan masalah awal yang ditemukan. Ketiga, pelaksanaan penelitian. Pada tahap ini, peneliti melakukan pengumpulan data penelitian yang berkaitan dengan keadaan pendidik serta sarana prasarana di satuan PAUD Santa Angela. Pengumpulan data penelitian dilakukan dengan menggunakan wawancara, observasi, dan dokumentasi. Keempat, tahap analisis data. Analisis data dilakukan menggunakan teknik analisis deskriptif model Miles \& Huberman.

\section{Data, Instrumen, dan Teknik Pengumpulan Data}

Data yang dikumpulkan dalam penelitian ini berupa data tentang keadaan pendidik dan sarana prasarana pendidikan di satuan PAUD Santa Angela Desa Compang Ndejing. Data tersebut diperoleh dari hasil wawancara, observasi, dan dokumentasi terhadap guru, siswa, orangtua, dokumen pembelajaran, bukti peningkatan kompetensi guru, serta sarana prasarana yang ada di satuan PAUD Santa Angela. Alat bantu yang digunakan peneliti untuk mengumpulkan data penelitian dalam penelitian ini berupa lembar observasi. Lembar observasi yang digunakan adalah lembar observasi keadaan pendidik dan sarana prasarana di satuan PAUD Santa Angela. Pada saat mengumpulkan data, peneliti menggunakan teknik wawancara, observasi, dan dokumentasi. Teknik wawancara digunakan untuk mendapatkan data tentang kualifikasi akademik pendidik, kompetensi yang dimiliki pendidik, dan sarana prasarana yang tersedia di satuan PAUD Santa Angela. Peneliti melalukan wawancara dengan anak, pendidik, dan orangtua. Teknik observasi digunakan untuk melihat, menyimak, dan mencatat sarana prasarana yang tersedia serta kompetensi guru dalam mengajar. Teknik dokumentasi digunakan untuk menelaah dokumen pembelajaran yang dibuat oleh guru, sertifikat peningkatan kompetensi guru, serta mengumpulkan foto-foto sarana prasarana.

Teknik analisis data yang digunakan dalam penelitian ini adalah adalah model Miles dan Huberman yaitu reduksi data, penyajian data, dan verifikasi data. Pada tahap reduksi data, peneliti merangkum data yang sudah diperoleh pada saat pengumpulan data, memilih hal-hal yang pokok sesuai dengan objek yang diteliti (potret pendidik dan sarana prasarana), fokus pada data-data yang penting yang berkaitan dengan potret pendidik dan sarana prasarana dan membuang data yang tidak perlu yang menurut peneliti tidak relevan dengan hasil data yang dibutuhkan peneliti. Dengan demikian, data yang telah direduksi akan memberikan gambaran yang lebih jelas dan memudahkan peneliti untuk melakukan 
pengumpulan data selanjutnya. Pada tahap penyajian data, peneliti membuat uraian-uraian singkat mengenai data yang telah direduksi untuk menemukan hubungan-hubungan antar data hasil reduksi sebagai temuan penelitian dan hasilnya kemudian dibahas untuk dijadikan hasil penelitian ini. Pada tahap verifikasi, peneliti meninjau kembali data yang sudah disajikan dalam bentuk narasi, melihat apakah masih ada data yang belum menjawab tujuan penelitian, apakah ada data yang tidak perlu dimasukkan atau masih ada data yang belum valid/sesuai dan perlu diteliti lagi kemudian dibuat kesimpulan yang sesuai dengan bukti-bukti penelitian.

\section{HASIL PENELITIAN DAN PEMBAHASAN Potret Pendidik di Satuan PAUD Santa Angela}

Berdasarkan penelitian yang telah dilaksanakan, ditemukan bahwa jumlah pendidik di satuan PAUD Santa Angela adalah 1 orang dengan kualifikasi akademik tamatan SMA (Sekolah Menengah Atas). Pendidik tersebut melayani 34 orang anak (usia 4-6 tahun 31 orang, dengan rincian laki-laki berjumlah 17 orang dan perempuan 14 orang dan ditemukan terdapat anakanak yang berusia 2 tahun sejumlah 1 orang, serta berusia 3 tahun sejumlah 2 orang. Tiga puluh empat orang anak tersebut mendapatkan layanan pendidikan dalam sebuah ruangan yang sama tanpa pengelompokkan berdasarkan usia. Anak-anak tidak dikelompokkan berdasarkan usia karena keterbatasan tenaga pendidik serta ruangan yang terlalu kecil dan hanya ada satu untuk semua aktivitas di satuan PAUD tersebut. Kurangnya pemahaman pendidik tentang jenis-jenis layanan di satuan PAUD berdasarkan usia juga mempengaruhi pengelolaan pembelajaran yang kurang sesuai. Para orangtua menyampaikan bahwa tidak apa-apa anak-anak hanya belajar dalam keadaan seperti itu, asalkan anak-anak mau belajar di satuan PAUD agar memiliki bekal untuk masuk sekolah dasar. Menurut penuturan para orangtua, anak-anak yang mendapat bimbingan di satuan PAUD Santa Angela sebagian besar memiliki pengetahuan dan keterampilan yang lebih pada saat masuk sekolah dasar bahkan ada yang selalu memperoleh juara kelas dibandingkan dengan anak-anak yang tidak mendapatkan layanan pendidikan di satuan PAUD sebelumnya. Kenyataan tersebut sejalan dengan hasil kajian sebelumnya yang dilakukan oleh Rizal pada tahun 2014, menunjukkan bahwa anak yang mendapatkan layanan pendidikan di satuan PAUD memiliki perkembangan yang lebih baik dibandingkan dengan anak yang tidak mendapatkan layanan pendidikan di satuan PAUD (Rizal, 2014).

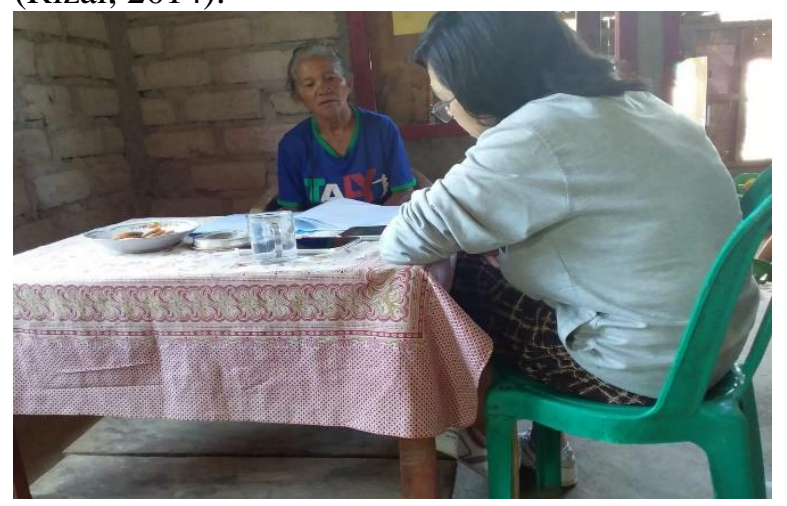

Gambar 1. Wawancara dengan Orangtua Anak PAUD Santa Angela

Berkaitan dengan kompetensi personal, pendidik di satuan PAUD Santa Angela sudah terlihat mampu menyayangi anak secara tulus, penuh perhatian, peka dan cepat tanggap terhadap perilaku anak, berperilaku baik dan menjadi teladan bagi anak, serta tidak membeda-bedakan anak satu dengan lainnya yang nampak dalam interaksi antara anak dengan guru sehari-hari. Anak-anak pun sangat menyukai guru mereka dan betah berada di sekolah.

Kompetensi sosial guru PAUD Santa Angela sudah ditunjukkan melalui kemampuan guru dalam berkomunikasi dengan siswa, orangtua siswa, sesama guru, maupun masyarakat. Guru PAUD Santa Angela juga bergabung dalam anggota komunitas UBSP (Usaha Bersama Simpan Pinjam) sehingga kemampuannya dalam bersosialisasi sangat baik. Komunikasi yang terjalin dengan orangtua juga sangat baik, guru selalu membicarakan kepada orangtua mengenai perkembangan anak dan hal-hal lainnya dan orangtua menerima dan bekerja sama dengan sangat baik.

Pendidik PAUD Santa Angela masih belum mampu mengimplemetasikan pengetahuannya mengenai tahapan pertumbuhan dan perkembangan anak berdasarkan usia, memahami pelayanan PAUD secara holistik integratif, serta memiliki keterampilan untuk menerapkan pendekatan, strategi, metode, serta media dalam menyampaikan materi pembelajaran yang sesuai dengan karakteristik anak usia dini dalam seluruh aktivitas di satuan PAUD. Hal tersebut terlihat dari layanan pendidikan yang diberikan terutama dalam memberikan rangsangan pendidikan tidak berdasarkan pengelompokkan usia, karakteristik, dan tahapan perkembangan berdasarkan usia anak (hal ini juga disebabkan kekurangan ruangan). 
Aktivitas di satuan PAUD setiap hari hanya menekankan pada kemampuan membaca, menulis, dan berhitung tanpa memperhatikan aspek-aspek perkembangan anak yang seharusnya distimulasi sesuai usia anak. hasil penelitian menunjukkan bahwa pendidik PAUD mengetahui teori tentang perkembangan anak, standar tingkat pencapaian perkembangan anak, alat permainan edukatif, metode pembelajaran di PAUD tetapi tidak mampu mengimplementasikan pengetahuan tersebut dalam kegiatan sehari-hari di satuan PAUD. Kurangnya kompetensi profesional guru PAUD Santa Angela disebabkan minimnya mengikuti kegiatan untuk meningkatkan kompetensi seperti seminar, workshop, serta pelatihan, apalagi guru hanya memiliki pendidikan terakhir di SMA.

Sama halnya dengan kemampuan profesional, pendidik di satuan PAUD Santa Angela masih kurang memiliki kemampuan untuk mengimpelementasikan pemahamannya tentang karakteristik siswa, merancang pembelajaran, melaksanakan pembelajaran, mengevaluasi pembelajaran untuk mengoptimalkan segala potensi yang siswa miliki. Hal tersebut tampak dari dokumen perencanaan yang lengkap tetapi tidak sejalan dengan penerapannya saat anak-anak beraktivitas. Kegiatan yang dilaksanakan seharihari didominasi oleh kegiatan membaca, menulis, dan berhitung tanpa berpatokan pada rencana pembelajaran yang telah disusun. Hal lain tampak pada hasil evaluasi perkembangan peserta didik. Guru belum memahami cara membuat penilaian autentik serta menerapkan teknik-teknik penilaian seperti catatan anekdot, catatan hasil karya, serta unjuk kerja.

\section{Potret Sarana dan Prasarana di Satuan PAUD Santa Angela}

Ketersediaan sarana dan prasarana di satuan PAUD Santa Angela sungguh masih memprihatinkan. Ruangan yang dipakai untuk aktivitas guru dan anak dalam menjalankan layanan berupa rangsangan pendidikan, pegasuhan, dan perlindungan hanya ada satu ruangan. Ruangan ini digunakan untuk segala jenis kegiatan di satuan PAUD Santa Angela termasuk pertemuan dengan orangtua anak. Ruangan ini berlantai tanah, berdinding anyaman bambu, dan berdebu. Jika anak bermain lego, anak akan bermain langsung di lantai tanah.

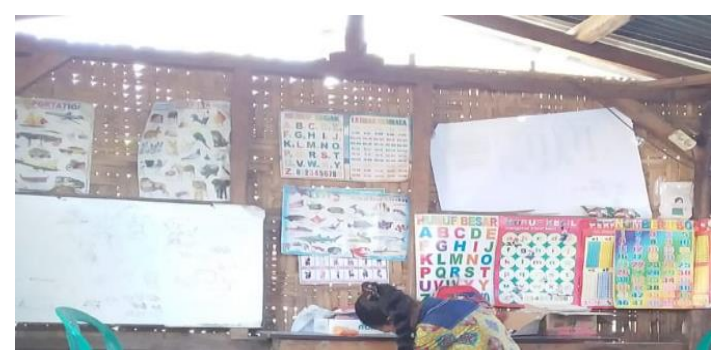

Gambar 2. Sarana Prasarana Pembelajaran di PAUD Santa Angela

Area bermain outdoor hanya dilengkapi dengan 1 buah ayunan yang bertiang kayu. Ayunan tersebut juga jarang digunakan oleh anak-anak karena takut terjatuh ke tanah dan terluka. Ayunan tersebut terlihat sewaktu-waktu dapat ambruk jika anakanak menggunakannya untuk bermain. Alat bermain outdoor lainnya tidak tersedia. Halaman yang ada sangat gersang dan anak-anak pada saat istirahat hanya berdiri atau duduk sambil sesekali berlarian di halaman tersebut. Tidak ditemukan ruangan lain selain sebuah ruangan yang dipakai untuk segala bentuk aktivitas di satuan PAUD Santa Angela. Tidak terdapat ruang guru, ruang kepala sekolah, ruang UKS, perpustakaan, ruang konsultasi, tempat parkir ruang cuci, bahkan ruang serbaguna. Toilet yang digunakan oleh anak dan guru merupakan toilet bersama yang merupakan milik dari pemilik lahan tempat ruangan sekolah satuan PAUD Santa Angela dibangun. Tidak ada jaringan telekomunikasi dan IT khusus, alat komunikasi menggunakan handpone milik guru satuan PAUD Santa Angela.

Tidak ada bus khusus untuk menjemput dan mengantar anak. Setiap anak akan diantar dan dijemput oleh orangtua masing-masing anak. Para orangtua menyampaikan bahwa jika memiliki kesibukan lain di pagi atau siang hari maka anakanak akan diminta untuk tidak masuk sekolah pada hari tersebut karena tidak bisa mengantar dan menjemput anak, walaupun demikian para orangtua senang karena anak-anak bisa belajar gratis di satuan PAUD tersebut, setidaknya masih ada wadah belajar bagi anak-anak mereka.

\section{Potret Pendidik di Satuan PAUD Santa Angela}

Kompetensi guru PAUD dimaknai sebagai keahlian yang berfungsi untuk memberikan perubahan perkembangan pada anak usia dini sesuai dengan yang diharapkan (Saripudin, 2019). Guru PAUD sebagai pendidik diharapkan memiliki pengetahuan, sikap, dan keterampilan yang dapat dilaksanakan dalam seluruh proses pembelajaran di satuan PAUD. Pendidik PAUD sebagai perencana, pelaksana, dan evaluator pelaksanaan pembelajaran di satuan PAUD merupakan tonggak utama dalam penyelenggaraan suatu lembaga pendidkan anak usia dini. Oleh karena itu, seorang pendidik PAUD seharusnya memiliki standar kualitas tertentu seperti memiliki memiliki ijazah S1 kePAUDan atau psikologi dari program studi yang terakreditasi (Kemendikbud, 2014). 
Sedangkan berdasarkan hasil penelitian yang telah diuraikan di atas, pendidik di satuan PAUD Santa Angela memiliki kualifikasi akademik tamatan SMA (Sekolah Menengah Atas). Dalam pelaksanaan pembelajaran, guru di satuan PAUD Santa Angela melayani 34 orang anak dengan karakteristik dan usia yang berbeda yakni usia 4-6 tahun 31 orang, dengan rincian laki-laki berjumlah 17 orang dan perempuan 14 orang dan ditemukan terdapat anak-anak yang berusia 2 tahun sejumlah 1 orang, serta berusia 3 tahun sejumlah 2 orang. Tiga puluh empat orang anak tersebut mendapatkan layanan pendidikan dalam sebuah ruangan yang sama tanpa pengelompokkan berdasarkan usia. Semua anak mendapatkan stimulasi yang sama tanpa memperhatikan tingkat pencapaaian perkembangan yang seharusnya dicapai oleh anak sesuai dengan tahapan usia anak. Sementara, seharusnya perbandingan antara jumlah guru dan anak yakni usia lahir hingga 2 tahun $1: 4$, usia 2 sampai 4 tahun 1 : 8 , dan usia 4 sampai 6 tahun $1: 15$. Jenis layanan yang diberikan dibagi sesuai tingkatan usia yakni lahir sampai 2 tahun, 2 sampai 4 tahun, dan 4 sampai 6 tahun (Kemendikbud, 2014). Anak-anak tidak dikelompokkan berdasarkan usia karena keterbatasan tenaga pendidik serta ruangan yang terlalu kecil dan hanya ada satu untuk semua aktivitas di satuan PAUD tersebut. Kurangnya pemahaman pendidik tentang jenis-jenis layanan di satuan PAUD berdasarkan usia juga mempengaruhi pengelolaan pembelajaran yang kurang sesuai.

Pendidik di satuan PAUD Santa Angela menyayangi anak secara tulus, penuh perhatian, peka dan cepat tanggap terhadap perilaku anak, berperilaku baik dan menjadi teladan bagi anak, serta tidak membeda-bedakan anak satu dengan lainnya yang nampak dalam interaksi antara anak dengan guru sehari-hari. Anak-anak pun sangat menyukai guru mereka dan betah berada di sekolah. Kemampuan tersebut menunjukkan bahwa pendidik di satuan PAUD Santa Angela sudah memiliki kompetensi personal sebagai pendidik PAUD (Christianti, 2012). Guru PAUD Santa Angela juga mampu menjalin komunikasi dengan siswa, orangtua siswa, sesama guru, maupun masyarakat. Dalam standar tentang pendidik dan tenaga kependidikan dituliskan bahwa seorang guru PAUD harus memiliki kompetensi personal dan sosial (Kemendikbud, 2014). Selain kompetensi personal dan sosial, guru PAUD juga perlu memiliki kompetensi profesional dan pedagogik.
Dari hasil penelitian yang sudah diuraikan sebelumnya, pendidik PAUD Santa Angela masih belum mampu mengimplemetasikan pengetahuannya mengenai tahapan pertumbuhan dan perkembangan anak berdasarkan usia, memahami pelayanan PAUD secara holistik integratif, serta memiliki keterampilan untuk menerapkan pendekatan, strategi, metode, serta media dalam menyampaikan materi pembelajaran yang sesuai dengan karakteristik anak usia dini dalam seluruh aktivitas di satuan PAUD. Padahal seharusnya, Guru PAUD memiliki kompetensi profesional jika memiliki kemampuan untuk memahami tahapan pertumbuhan dan perkembangan anak berdasarkan usia, memahami pelayanan PAUD secara holistik integratif, serta memiliki keterampilan untuk menerapkan pendekatan, strategi, metode, serta media dalam menyampaikan materi pembelajaran yang sesuai dengan karakteristik anak usia dini (Christianti, 2012). Hal tersebut terlihat dari layanan pendidikan yang diberikan terutama dalam memberikan rangsangan pendidikan tidak berdasarkan pengelompokkan usia, karakteristik, dan tahapan perkembangan berdasarkan usia anak. Sama halnya dengan kemampuan profesional, pendidik di satuan PAUD Santa Angela masih kurang memiliki kemampuan untuk mengimpelementasikan pemahamannya tentang karakteristik siswa, merancang pembelajaran, melaksanakan pembelajaran, mengevaluasi pembelajaran untuk mengoptimalkan segala potensi yang siswa miliki. Hal tersebut tampak dari dokumen perencanaan yang lengkap tetapi tidak sejalan dengan penerapannya saat anak-anak beraktivitas. Kegiatan yang dilaksanakan seharihari didominasi oleh kegiatan membaca, menulis, dan berhitung tanpa berpatokan pada rencana pembelajaran yang telah disusun. Hal lain tampak pada hasil evaluasi perkembangan peserta didik. Guru belum memahami cara membuat penilaian autentik serta menerapkan teknik-teknik penilaian seperti catatan anekdot, catatan hasil karya, serta unjuk kerja. Guru PAUD memiliki kompetensi pedagogik jika seorang guru memiliki pemahaman tentang karakteristik siswa, mampu merancang pembelajaran, melaksanakan pembelajaran, mengevaluasi pembelajaran untuk mengoptimalkan segala potensi yang siswa miliki. Kompetensi sosial seorang guru PAUD dapat ditunjukkan melalui kemampuan guru dalam menyesuaikan diri dengan lingkungan dan berkomunikasi secara efektif dengan siswa, orangtua siswa, sesama guru, maupun masyarakat (Christianti, 2012). Potret pendidik PAUD yang 
masih belum memiliki kemmpuan profesional dan pedagogik yang mumpuni seperti ini merupakan sebagian potret pendidik di satuan PAUD yang berada dalam wilayah Kabupaten Manggarai Timur. Diharapkan hasil penelitian ini menjadi dasar bagi pemerintah Kabupaten Manggarai Timur untuk semakin mengedepankan kualitas pendidik PAUD dalam penerapan kebijakan dan penyerapan anggaran pendidikan di Manggarai Timur.

\section{Potret Sarana dan Prasarana di Satuan PAUD Santa Angela}

Sarana dan prasarana merupakan penunjang aktivitas belajar pada satuan PAUD yang memiliki andil dalam proses pembelajaran. Ketersediaan sarana dan prasarana membantu guru dan siswa melaksanakan kegiatan di satuan PAUD dengan lancar dan memudahkan guru dan siswa menjelaskan, mempraktikkan, serta memahami setiap tema atau subtema yang akan dipelajari. Menurut Mulyasa (2004), sarana pendidikan adalah seperangkat alat lengkap yang digunakan secara langsung untuk mendukung kelancaran aktivitas belajar dan mengajar, seperti ruanganruangan, meja, kursi, alat permainan edukatif, dan media pembelajaran. Prasarana pendidikan adalah perlengkapan yang secara tidak langsung ikut mendukung aktivitas belajar dan mengajar, seperti halaman, kebun, taman, dan jalan menuju tempat belajar (Fitriani, 2015).

Sedangkan dalam pedoman prasarana PAUD (2014), mendefenisikan prasarana pendidikan anak usia dini sebagai semua jenis alat, bahan, perlengkapan, atau benda-benda yang menunjang pelaksanaan kegiatan pendidikan, pengasuhan, dan perlindungan anak usia dini secara optimal seperti area bermain indoor dan outdoor, ruang guru, ruang kepala sekolah, ruang UKS, kamar mandi/toilet anak dan guru, perlengkapan di dalam dan di luar ruang belajar seperti; meja, kursi, lemari, loker, tempat hasil karya, dan lain-lain, dapur, tempat ibadah, perpustakaan, ruang konsultasi, tempat parkir, bus sekolah, ruang serbaguna, ruang cuci, jaringan telekomunikasi dan IT (Direktorat Pembinaan PAUD Kemdikbud, 2014). Dalam penelitian ini, peneliti lebih memaknai sarana dan prasarana PAUD sebagai fasilitas berupa lahan, bangunan, peralatan meubel, alat permainan edukatif, media pembelajaran, perlengkapan kantor, tempat sampah, alat komunikasi, dan transportasi yang mendukung keberlangsungan kegiatan belajar dan mengajar di PAUD. Dalam merancang sarana dan prasarana di PAUD, pengelola dan guru PAUD wajib mempertimbangkan keleluasaan anak dalam melakukan aktivitas, kenyamanan anak dalam menggunakan sarana dan prasarana, tingkat kemampuan anak dalam menggunakan sarana dan prasarana, dan tingkat kepekaan anak dalam menggunakan sarana dan prasarana (Direktorat Pembinaan PAUD Kemdikbud, 2014).

Sarana dan prasarana yang lengkap seperti yang telah diuraikan di atas idealnya dimiliki oleh setiap satuan PAUD di mana saja satuan PAUD tersebut didirikan. Sarana dan prasarana yang kurang lengkap dan memadai dapat mengakibatkan layanan rangsangan yang diberikan kepada anak menjadi kurang optimal (Jannah, 2019). Pemerintah perlu mengupayakan pemerataan kualitas semua satuan PAUD di seluruh Indonesia agar tercipta generasi masa depan yang cemerlang dan berdaya saing di ranah global. Berdasarkan hasil penelitian ini, ruangan yang dipakai untuk aktivitas guru dan anak dalam menjalankan layanan berupa rangsangan pendidikan, pegasuhan, dan perlindungan hanya ada satu ruangan. Ruangan ini digunakan untuk segala jenis kegiatan di satuan PAUD Santa Angela termasuk pertemuan dengan orangtua anak. Ruangan ini berlantai tanah, berdinding anyaman bambu, dan berdebu. Area bermain outdoor hanya dilengkapi dengan 1 buah ayunan yang bertiang kayu. Halaman yang ada sangat gersang dan anak-anak pada saat istirahat hanya berdiri atau duduk sambil sesekali berlarian di halaman tersebut. Tidak ditemukan ruangan lain selain sebuah ruangan yang dipakai untuk segala bentuk aktivitas di satuan PAUD Santa Angela. Tidak terdapat ruang guru, ruang kepala sekolah, ruang UKS, perpustakaan, ruang konsultasi, tempat parkir ruang cuci, bahkan ruang serbaguna. Toilet yang digunakan oleh anak dan guru merupakan toilet bersama yang merupakan milik dari pemilik lahan tempat ruangan sekolah satuan PAUD Santa Angela dibangun. Tidak ada jaringan telekomunikasi dan IT khusus, alat komunikasi menggunakan handpone milik guru satuan PAUD Santa Angela juga tidak ada bus khusus untuk menjemput dan mengantar anak. kenyataan tersebut berbanding terbalik dengan ketentuan dalam pedoman prasarana PAUD (2014), bahwa sarana parasarana di satuan PAUD meliputi area bermain indoor dan outdoor, ruang guru, ruang kepala sekolah, ruang UKS, kamar mandi/toilet anak dan guru, perlengkapan di dalam dan di luar ruang belajar seperti; meja, kursi, lemari, loker, tempat hasil karya, dan lain-lain, dapur, tempat ibadah, perpustakaan, ruang konsultasi, tempat parkir, bus sekolah, ruang serbaguna, ruang cuci, jaringan telekomunikasi dan IT (Direktorat Pembinaan PAUD Kemdikbud, 2014). 
Keterbatasan sarana prasarana di satuan PAUD Santa Angela ini merupakan potret sebagian satuan PAUD yang tersebar di berbagai tempat di wilayah Kabupaten Manggarai Timur. Diharapkan hasil penelitian ini menjadi dasar bagi pemerintah Kabupaten Manggarai Timur untuk semakin mengedepankan kualitas pendidik PAUD dalam penerapan kebijakan dan penyerapan anggaran pendidikan di Manggarai Timur.

Sarana prasarana yang sangat baik tentu saja akan mendukung keberlangsungan dan kualitas layanan pendidikan di satuan PAUD, seperti hasil penelitian sebelumnya yang dilakukan oleh Rodah, dkk., (Pelagia Rodah, Muhamad Ali, 2013) bahwa sarana prasarana sangat penting dalam dunia pendidikan, sarana prasarana sangat mendukung pelaksanaan proses belajar mengajar di satuan PAUD. Selain itu, ketersediaan sarana pra sarana yang memadai dapat memberikan pengaruh yang positif terhadap kompetensi guru dan efektivitas pemberian layanan pendidikan di satuan PAUD (Kurniawan, 2017). Dengan demikian, kelengkapan sarana prasarana serta kemampuan pendidik dalam memberikan layanan di satuan PAUD merupakan salah satu bentuk mempersiapkan anak usia dini yang memiliki perkembangan optimal sebagai generasi penerus di masa yang akan datang agar mampu menghadapi tantangan global yang semakin berkembang pula.

\section{SIMPULAN}

Potret satuan PAUD Santa Angela merupakan gambaran wajah satuan PAUD di Kabupaten Manggarai Timur yang masih belum sepenuhnya merasakan kehadiran pemerintah dalam perencanaan, pelaksanaan, maupun evaluasi keberlangsungannya dalam bentuk peningkatan kualitas pendidik, pengadaan sarana prasarana, serta pelibatan stakeholder dalam mewujudkan pemberian layanan optimal bagi pendidikan, pengasuhan, dan perlindungan bagi anak usia dini. Kualifikasi akademik pendidik PAUD serta ketersediaan sarana prasarana yang belum memenuhi standar di satuan PAUD Santa Angela ini dapat menjadi tolok ukur pemerintah daerah dalam mempersiapkan generasi di masa mendatang yang diharapkan berkualitas sehinga mampu bersaing secara lokal, nasional, bahkan di ranah global. Kerjasama dari berbagai pihak sangat diharapkan demi terwujudnya satuan PAUD berkualitas di setiap desa. Selain itu, pendidik juga perlu memiliki kesadaran untuk meningkatkan kompetensinya melalui keikutsertaan dalam berbagai kegiatan peningkatan kompetensi yang diselenggarakan oleh berbagai pihak.

\section{DAFTAR PUSTAKA}

Christianti, M. (2012). Profesionalisme Pendidik Anak Usia Dini. Profesionalisme Pendidik Anak Usia Dini, 1(1). https://doi.org/10.21831/jpa.v1i1.2923

Direktorat Pembinaan PAUD Kemdikbud. (2014). Pedoman Prasarana Pendidikan Anak Usia Dini. 33. http://www.paud.kemdikbud.go.id

Fadilah, C., Rini, R., \& Nawangsasi, D. (2002). Motivasi Kerja Guru PAUD dan Kompetensi Pedagogik. Jurnal Pendidikan Anak, 39(4), 274287.

Jannah, N. F. (2019). Pengaruh Sarana Prasarana terhadap Pembelajaran Anak di TK Aisyiyah SeKecamatan Colomadu.

Kemendikbud. (2014). Peraturan Menteri Pendidikan dan Kebudayaan Republik Indonesi No 137 Tahun 2014 tentang Standar Nasional Pendidikan Anak Usia Dini. 1-15.

Kurniawan, N. (2017). Pengaruh Standart Sarana dan Prasarana terhadap Efektifitas Pembelajaran di TK Al-Firdaus. Jurnal Warna: Jurnal Pendidikan Dan Pembelajaran Anak Usia Dini, 2(2), 14-26.

Mustika. (2015). Kompetensi Pedagogik Guru Taman Kanak-kanak Negeri Pembina di Tarakan. Jurnal Kebijakan Dan Pengembangan Pendidikan, 3(1), 93-98.

Muzaqi, M. (2008). Penerapan Kompetensi Pedagogis Tenaga Pendidik PAUD. VISI, 3(2), 131-143.

Pelagia Rodah, Muhamad Ali, D. (2013). Manajemen Sarana Prasarana Pendidikan Anak Usia Dini Di Taman Kanak-Kanak. Journal of Chemical Information and Modeling, 53(9), 1689-1699. https://doi.org/10.1017/CBO9781107415324.004

Puspita, W. A. (2010). Pendidik Pendidikan Anak Usia Dini (PAUD) Sebagai Model Perilaku Anak Usia Dini. VISI, 5(2), 209-215. https://doi.org/10.21009/jiv.0502.9

Rizal. (2014). Perbedaan Tingkat Perkembangan Anak Usia Prasekolah yang Sekolah TK dan Anak yang Tidak Sekolah TK di Desa Banarsari Kec. Bantarbolang Pemalang. FIKkes Jurnal Keperawatan, 7(1), 36-48. https://doi.org/10.1017/CBO9781107415324.004

Saripudin, A. (2019). Kompetensi Guru Pendamping PAUD dalam Memenuhi Standar Layanan PAUD Non Formal. Jurnal Pendidikan Anak, 5(2), 6777.

Shidiq, U., \& Choiri, M. (2019). Metode Penelitian Kualitatif di Bidang Pendidikan. In Journal of Chemical Information and Modeling (Vol. 53, Issue

9). https://doi.org/10.1017/CBO9781107415324.004 